\title{
Geographical information system-based morphometric analysis of Bharathapuzha river basin, Kerala, India
}

\author{
N. S. Magesh • K. V. Jitheshlal • N. Chandrasekar • \\ K. V. Jini
}

Received: 7 December 2012/ Accepted: 3 March 2013/Published online: 15 March 2013

(C) The Author(s) 2013. This article is published with open access at Springerlink.com

\begin{abstract}
A morphometric analysis of Bharathapuzha river basin has been carried out using geoprocessing techniques in GIS. This technique is found relevant for the extraction of river basin and its drainage networks. The extracted drainage network was classified according to Strahler's system of classification and it reveals that the terrain exhibits dendritic to sub-dendritic drainage pattern. The Bharathapuzha drainage basin is sprawled over an area of $5,988.56 \mathrm{~km}^{2}$. The study area was designated as seventh-order basin and lower order streams mostly dominate the basin with the drainage density value of $1.07 \mathrm{~km} / \mathrm{km}^{2}$. The slope of basin varied from $0^{\circ}$ to $70^{\circ}$ and the slope variation is chiefly controlled by the local geology and erosion cycles. The elongation ratio of the basin is 0.57 indicating that the study area is elongated with moderate relief and steep slopes. The drainage texture of the basin is 7.78 which indicates an intermediate texture that exists over the region. Hence, from the study, it can be concluded that remote sensing data (SRTM-DEM) coupled with geoprocessing techniques prove to be a competent tool in
\end{abstract}

N. S. Magesh · K. V. Jitheshlal $(\bowtie) \cdot$ N. Chandrasekar Centre for Geotechnology, Manonmaniam Sundaranar University, Tirunelveli, Tamil Nadu 627012, India e-mail: laljithenviro@gmail.com

N. S. Magesh

e-mail: mageshissivan@gmail.com

N. Chandrasekar

e-mail: profncsekar@gmail.com

\section{K. V. Jini}

Research and Post Graduate Department of Geology and Environmental Science, Christ College, Irinjalakuda, Thrissur, Kerala 680125, India e-mail: kvjini@gmail.com morphometric analysis and the data can be used for basin management and other hydrological studies in future.

Keywords Morphometric analysis - Bharathapuzha river basin · GIS · Geoprocessing · Kerala · India

\section{Introduction}

The development of a drainage system over space and time is influenced by several variables such as geology, structural components, geomorphology, soil and vegetation of an area through which it flows. Geomorphometry is the measurement and mathematical analysis of earth's surface and its dimensions of the landforms (Clarke 1996). Morphometric analysis of a river basin provides a quantitative description of the drainage system, which is an important aspect of the characterization of basins (Strahler 1964). It is important in any hydrological investigation like assessment of groundwater potential, groundwater management, basin management and environmental assessment.

Various hydrological phenomena can be correlated with the physiographic characteristics of an drainage basin such as size, shape, slope of the drainage area, drainage density, size and length of the contributories, etc. (Rastogi and Sharma 1976; Magesh et al. 2012a). The morphometric analysis can be performed through measurement of linear, aerial, relief, gradient of channel network and contributing ground slope of the basin (Nautiyal 1994; Nag and Chakraborty 2003; Magesh et al. 2012b). The dynamic nature of runoff is controlled by the geomorphologic structure of the catchment area and the induced runoff is very sensitive towards the morphometric characteristics of the contributing area (Rudraiah et al. 2008). In India, National Institute of Hydrology (1993) has carried out hydro-geomorphological 
studies of various basins and their analyses were based on linear, aerial and relief aspects using different mathematical equations. Various morphometric parameters such as drainage pattern, stream order, bifurcation ratio, drainage density and other linear aspects are studied using remote sensing technique and topographical map (Mesa 2006). The surface runoff and flow intensity of the drainage system can be estimated using the geomorphic features associated with morphometric parameters (Ozdemir and Bird 2009). Pioneer work on basin morphometry has been carried out by Horton (1932, 1945), Miller (1953), Smith (1950), and Strahler (1964). Based on their ideology, similar work has been emerged throughout the world by different researchers using different techniques. In India, morphometric studies of various drainage basins have been carried out by Rastogi and Sharma (1976), Nautiyal (1994), Nag and Chakraborty (2003), Rudraiah et al. (2008), Magesh et al. (2012a, b), John Wilson et al. (2012), and Magesh and Chandrasekar (2012). Most of them have used GIS and remote sensing technique for the estimation of morphometric parameters because the results obtained were reliable and accurate.

Application of remote sensing provides a reliable source for the preparation of various thematic layers for morphometric analysis. The digital elevation data can be used for generating the elevation model of a landscape to any extent. The resolution of the image may vary with respect to the satellite sensors. The processed DEM can be used for generating the stream network and other supporting layers
(Mesa 2006; Magesh et al. 2011). Geographical information systems (GIS) have been used for assessing various basin parameters, providing flexible environment and powerful tool for determination, interpretation and analysis of spatial information related to river basins. Geology, relief and climate are the primary determinants of a running water ecosystem functioning at the basin scale (Mesa 2006; John Wilson et al. 2012; Magesh and Chandrasekar 2012). Thus, detailed morphometric analysis of a basin is of great help in understanding the influence of drainage morphometry on landforms and their characteristics.

The present study depicts the process to evaluate the various morphometric parameters of Bharathapuzha river in Kerala using geoprocessing techniques in GIS (ArcGIS 10). The linear, relief and aerial parameters were computed mathematically to analyse the characteristics of different morphometric parameters for planning and development of the river basin.

\section{Study area}

The Bharathapuzha river basin lies between $10^{\circ} 15^{\prime}$ to $10^{\circ} 40^{\prime}$ North latitudes and $76^{\circ} 00^{\prime}$ to $76^{\circ} 35^{\prime}$ East longitudes and it covers Malappuram, Thrissur and Palakkad districts of Kerala, and Coimbatore district in Tamil Nadu, India (Fig. 1). It originates from the Western Ghats at an altitude of about $1,100 \mathrm{~m}$ above mean sea level, fed by its four main tributaries namely Kalpathypuzha, Gayathripuzha,
Fig. 1 Location map of the study area with stream networks

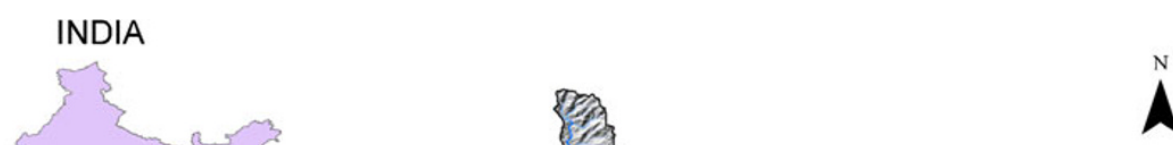

$\hat{A}$

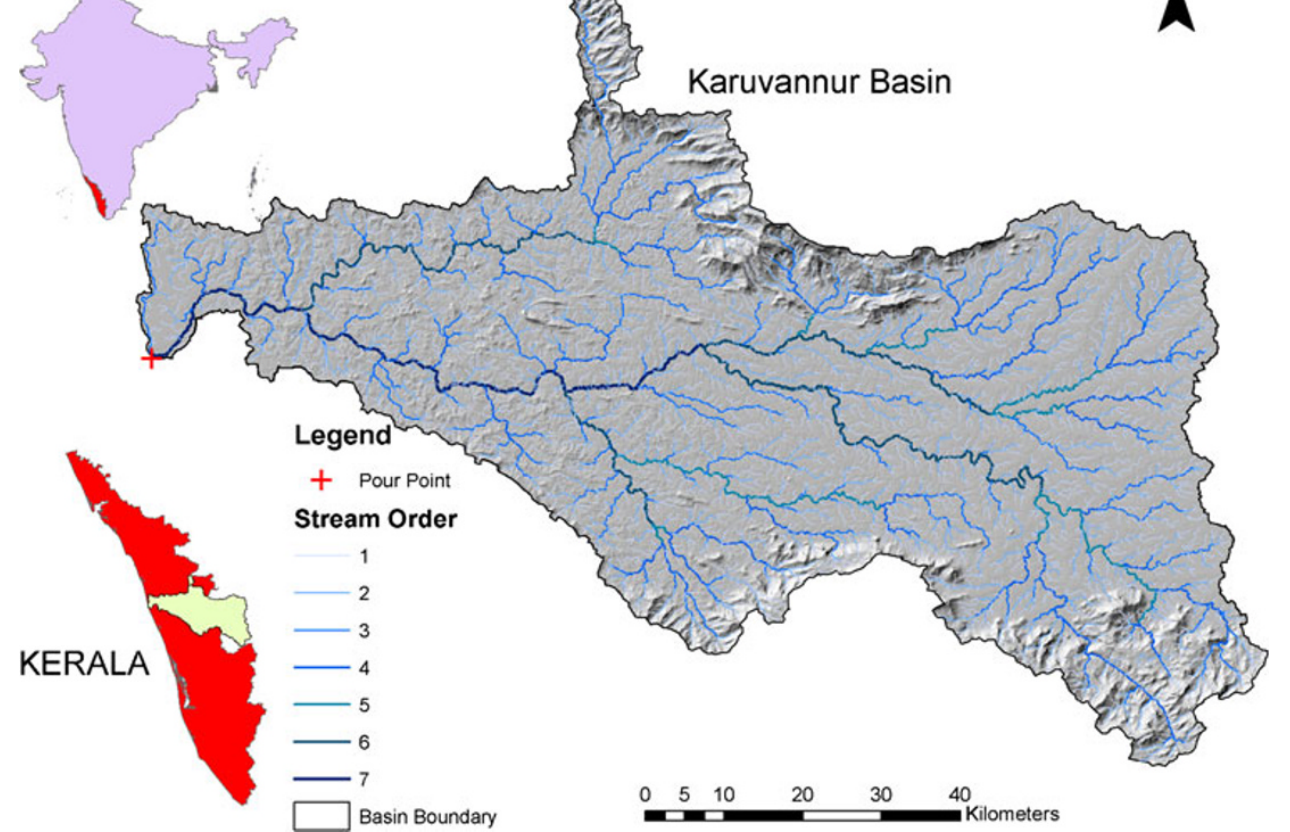




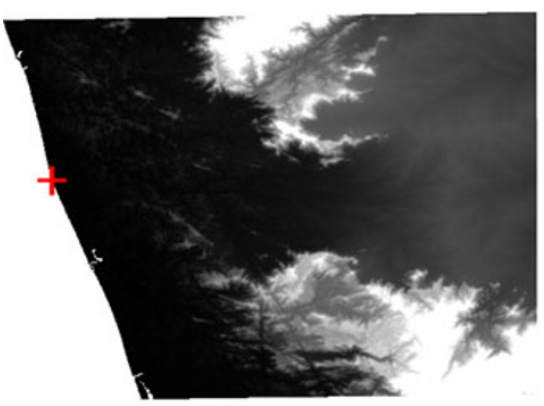

Projected Study Area DEM

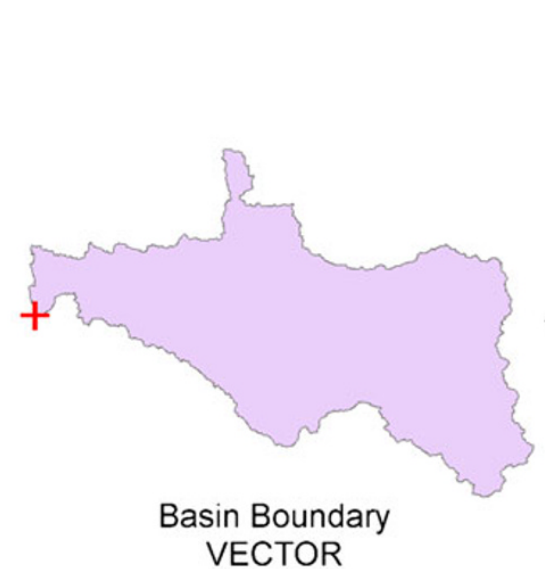

VECTOR

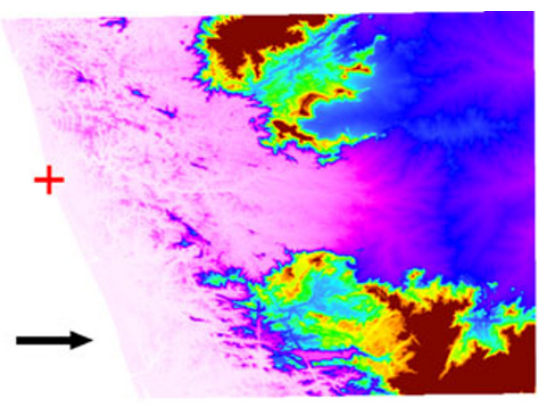

Filled Study Area DEM

+ Pour Point

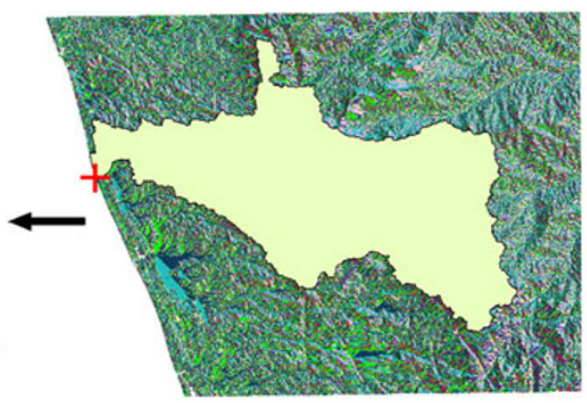

Basin Boundary RASTER

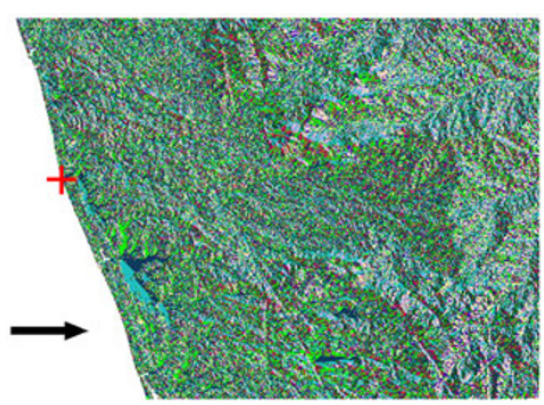

Flow Direction of the Study Area

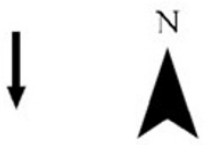

Watershed Analysis From ArcGIS Tool Box

Fig. 2 Extraction of the river basin boundary

Thootha and Chitturpuzha, which drain through highly varied geological and geomorphologic regions of Kerala. The study area has a total drainage area of $5,988.56 \mathrm{~km}^{2}$. Morphologically, the study has a well-developed flood plain and fluvial terrace of recent origin. The geology of the study area is characterized by Archaean crystalline formation (gneiss, schist, charnockite), Tertiary formations, sub-recent laterite and recent riverine alluvium (CGWB 2007). In general, the study area experiences tropical climate with an average annual temperature ranges from a maximum of $32.3^{\circ} \mathrm{C}$ dry season to a minimum of $23.3{ }^{\circ} \mathrm{C}$ in wet season. The rainfall in the study area is contributed mainly from the southwest monsoon (JuneSeptember) followed by northeast monsoon (OctoberDecember) with an average annual rainfall of 2,924.4 $\mathrm{mm}$. The humidity is higher during monsoon months from June to October.

\section{Methodology}

Digitizing stream network and assigning the stream order from a published topographic map for a large area is a tedious task. To overcome this problem, two extraction techniques have been developed for evaluating the morphometric parameters of a basin: extraction of river basin boundary and extraction of stream network from the river basin using SRTM DEM. The extracted basin and stream network are projected to the regional projection (WGS 1984 UTM Zone 43 N).

\section{Extraction of river basin}

The Bharathapuzha river basin is extracted from the Shuttle Radar Topographic Mission (SRTM) Digital Elevation Model (DEM) data provided by the Consultative group for International Agriculture Research Consortium for Spatial Information (CGIAR-CSI) with a spatial resolution of $90 \mathrm{~m}$. The contributing basin area was extracted with the help of various geoprocessing techniques in ArcGIS 10. The DEM and the pour point are the two input parameters required for the extraction purpose. A pour point is a user-supplied point to the cells of highest flow accumulation. The pour point of the basin is shown in Fig. 2. The systematic geoprocessing techniques required for the extraction of the basin are shown in Fig. 2. The result of this technique will create a polygon from the contributing area above a set of cells in a flow direction raster. 


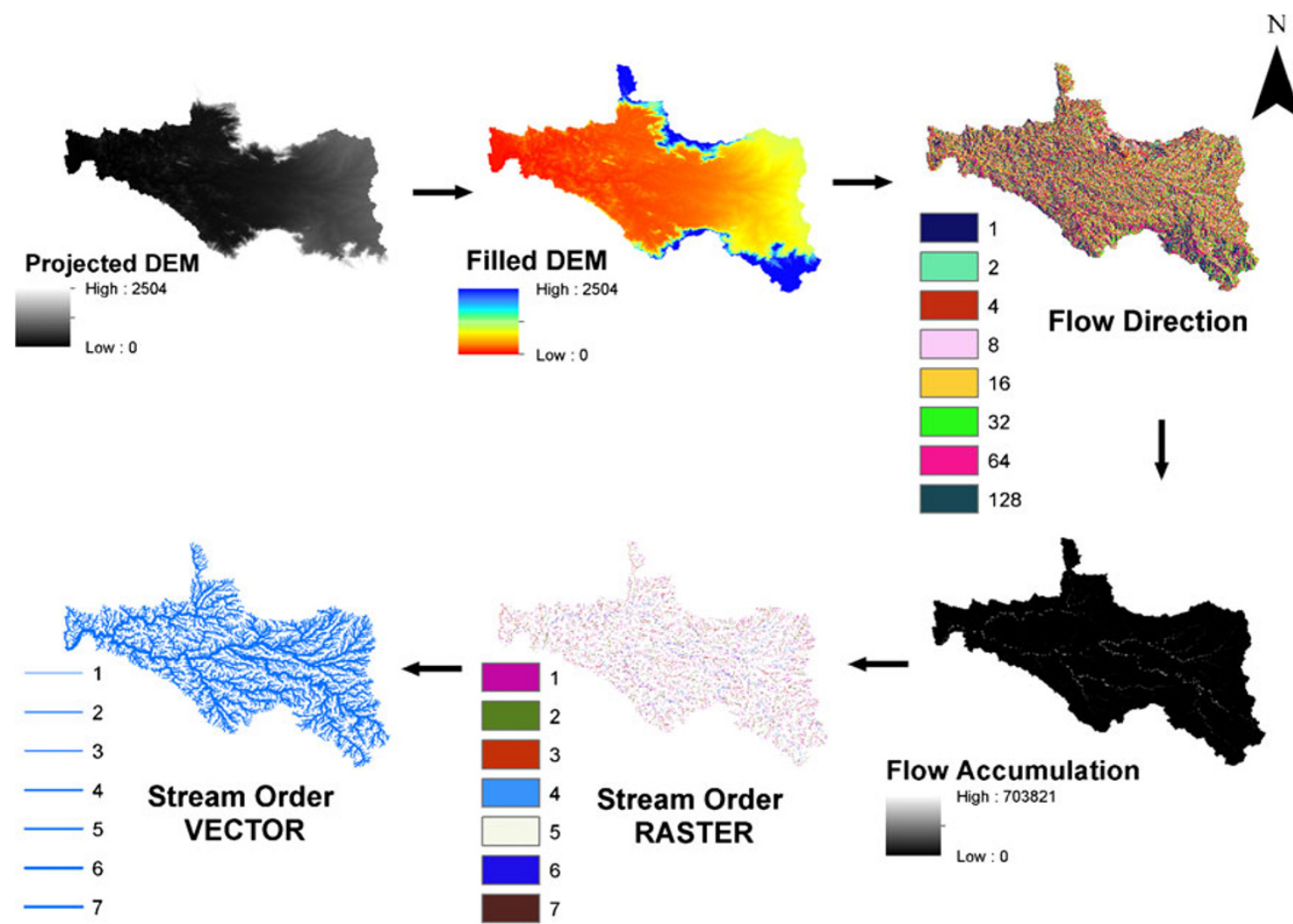

Fig. 3 Extraction of drainage networks from DEM

\section{Extraction of stream network}

The stream network of the study area is extracted from a series of geoprocessing tools (Fig. 3). The output of this technique will create a stream network grid with stream classification based on Strahler (1964). Strahler's system of classification designates a segment with no tributaries as a first-order stream. Where two first-order stream segments join, they form a second-order stream segment and so on. The highest stream order in the study area was computed as seventh. Manual corrections are made by merging the streams of same order with separated nodes. This technique requires two input model parameters: DEM and a minimum upstream area in hectares, which is the minimum drainage area required to create a stream segment. In this study, the minimum upstream area assigned for the subbasin is 5 ha. The output of the stream network is smoothened using a smooth line tool in ArcGIS 10.

To evaluate the basin morphometry, various parameters like stream number, stream order, stream length, stream length ratio, bifurcation ratio, basin length, basin area, relief ratio, elongation ratio, length of overland flow, drainage density, stream frequency, drainage texture, form factor and circulatory ratio have been analysed using the standard mathematical formulae given in Table 1. Moreover, the aspect and slope map of the study area were derived from the STRM DEM using the aspect and slope tool in ArcGIS 10 Spatial analyst module.

\section{Results and discussion}

The morphometric parameters of Bharathapuzha river basin have been examined and the results are given below (Table 2). The total drainage area of the Bharathapuzha basin is $5,988.56 \mathrm{~km}^{2}$. The drainage pattern is dendritic in nature and it is influenced by the general topography of the area.

Aspect

The aspect of a terrain is the direction to which it faces. Aspect influences vegetation type, precipitation patterns, snow melt and wind exposure. The compass direction of the aspect was derived from the output raster data value. 0 is true north; a $90^{\circ}$ aspect is to the east, and so forth. The aspect map of Bharathapuzha basin is shown in Fig. 4. The east facing slopes mainly occur in the study area, which has a higher moisture content and lower evaporation rate and hence has high vegetation index. Similar observation is also noticed in Tamiraparani sub-basin in which the east facing slopes are higher in the western part of the sub-basin (Magesh and Chandrasekar 2012). 
Table 1 Linear relief and areal morphometric parameters

\begin{tabular}{llll}
\hline S. No. & Parameters & Formulae & References \\
\hline 1 & Stream order (U) & Hierarchial rank & Strahler (1964) \\
2 & Stream length (Lu) & Length of the stream & Horton (1945) \\
3 & Mean stream length (Lsm) & $\mathrm{Lsm}=\mathrm{Lu} / \mathrm{Nu}$ & Strahler (1964) \\
4 & Stream length ratio (RL) & $\mathrm{RL}=\mathrm{Lu} /(\mathrm{Lu}-1)$ & Horton (1945) \\
5 & Bifurcation ratio (Rb) & $\mathrm{Rb}=\mathrm{Nu} / \mathrm{Nu}+1$ & Schumm (1956) \\
6 & Mean bifurcation ratio (Rbm) & $\mathrm{Rbm}=\mathrm{average}$ of bifurcation ratios of all order & Strahler (1957) \\
7 & Drainage density (Dd) & $\mathrm{Dd}=\mathrm{Lu} / A$ & Horton (1945) \\
8 & Drainage texture (T) & $T=\mathrm{Dd} \times \mathrm{Fs}$ & Smith (1950) \\
9 & Stream frequency (Fs) & $\mathrm{Fs}=\mathrm{Nu} / \mathrm{A}$ & Horton (1945) \\
10 & Elongation ratio (Re) & $\mathrm{Re}=D / L=1.128 \sqrt{A / L}$ & Schumm (1956) \\
11 & Circularity ratio (Rc) & $\mathrm{Rc}=4 \pi A / P^{2}$ & Strahler (1964) \\
12 & Form factor (Ff) & $\mathrm{Ff}=A / L^{2}$ & Horton (1945) \\
13 & Length of overland flow $(\mathrm{Lg})$ & $\mathrm{Lg}=1 / D \times 2$ & Horton (1945) \\
14 & Relief & $R=H-h$ & Hadley and Schumm (1961) \\
15 & Relief ratio & $\mathrm{Rr}=R / L$ & Schumm (1963) \\
\hline
\end{tabular}

Table 2 Results of morphometric analysis of Karuvannur Basin

\begin{tabular}{|c|c|c|c|c|c|c|c|c|}
\hline \multirow[t]{2}{*}{ S. no. } & \multirow[t]{2}{*}{ Parameters } & \multicolumn{7}{|c|}{ Stream orders } \\
\hline & & I & II & III & IV & $\mathrm{V}$ & VI & VII \\
\hline 1 & Stream order (total) & 3,458 & 744 & 170 & 38 & 11 & 4 & 1 \\
\hline 2 & Stream length $(\mathrm{Lu})(\mathrm{km})$ & $3,323.7$ & $1,468.4$ & 786.37 & 352.35 & 153 & 201.25 & 95.01 \\
\hline 3 & Mean stream length $(\mathrm{km})(\mathrm{Lsm})$ & 0.96 & 1.97 & 4.63 & 9.27 & 13.91 & 50.31 & 95.01 \\
\hline \multirow[t]{2}{*}{4} & Stream length ratio (RL) & & $\mathrm{II} / \mathrm{I}$ & $\mathrm{III} / \mathrm{II}$ & IV/III & V/IV & $\mathrm{VI} / \mathrm{V}$ & $\mathrm{VII} / \mathrm{VI}$ \\
\hline & & & 2.053 & 2.34 & 2 & 1.5 & 3.62 & 1.888 \\
\hline \multirow[t]{2}{*}{5} & Bifurcation ratio $(\mathrm{Rb})$ & & $\mathrm{I} / \mathrm{II}$ & II/III & III/IV & $\mathrm{IV} / \mathrm{V}$ & V/VI & VI/VII \\
\hline & & & 4.65 & 4.38 & 4.47 & 3.45 & 2.75 & 4 \\
\hline 6 & Mean bifurcation ratio (Rbm) & 3.95 & & & & & & \\
\hline 7 & Perimeter $(\mathrm{P})(\mathrm{km})$ & 569.04 & & & & & & \\
\hline 8 & Basin length (Lb) (km) & 153.8 & & & & & & \\
\hline 9 & Basin area $\left(\mathrm{km}^{2}\right)$ & $5,988.56$ & & & & & & \\
\hline 10 & Total relief $(\mathrm{R})(\mathrm{m})$ & 2,504 & & & & & & \\
\hline 11 & Relief ratio $(\mathrm{Rh})$ & 0.0163 & & & & & & \\
\hline 12 & Elongation ratio $(\mathrm{Re})$ & 0.57 & & & & & & \\
\hline 13 & Length of overland flow $(\mathrm{Lg})$ & 1.88 & & & & & & \\
\hline 14 & Drainage density (D) $\left(\mathrm{km} / \mathrm{km}^{2}\right)$ & 1.07 & & & & & & \\
\hline 15 & Stream frequency $(\mathrm{Fs})$ & 0.74 & & & & & & \\
\hline 16 & Texture ratio $(\mathrm{Rt})$ & 7.78 & & & & & & \\
\hline 17 & Form factor (Rf) & 0.25 & & & & & & \\
\hline 18 & Circulatory ratio $(\mathrm{Rc})$ & 0.23 & & & & & & \\
\hline
\end{tabular}

\section{Slope}

The slope of a terrain refers to the amount of inclination of physical feature, topographic landform to the horizontal surface. Slope analysis is an important parameter in morphometric studies. The slope elements, in turn are controlled by climato-morphogenic processes in areas having rock of varying resistance. According to Burrough (1986), the maximum rate of change in value from each cell to its neighbours is identified as slope grid. The degree of slope exhibited by Bharathapuzha river basin varies from $0^{\circ}$ to $70.59^{\circ}$. The slope map of the Bharathapuzha 
Fig. 4 Aspect map of Bharathapuzha river basin

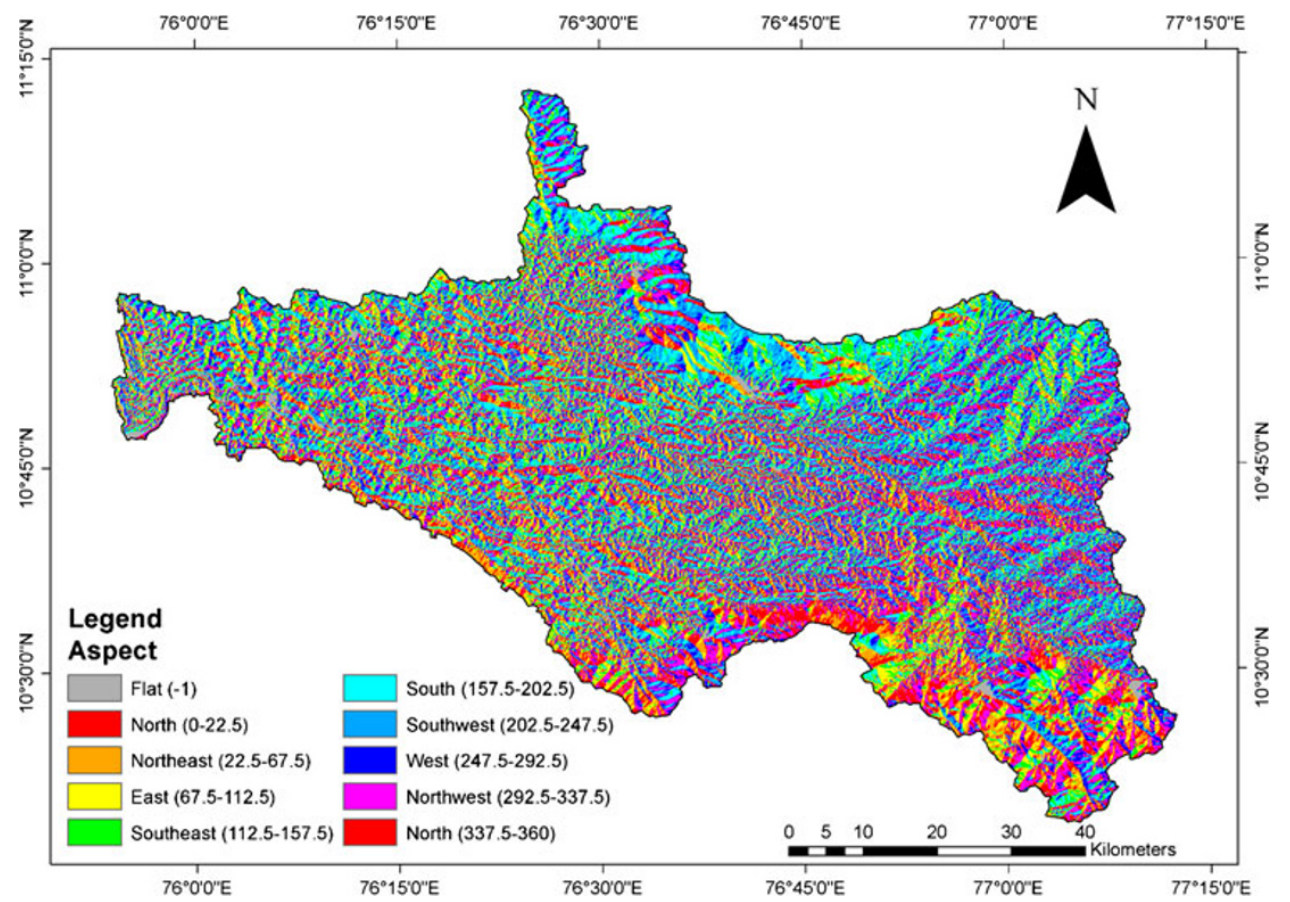

Fig. 5 Slope map of Bharathapuzha river basin

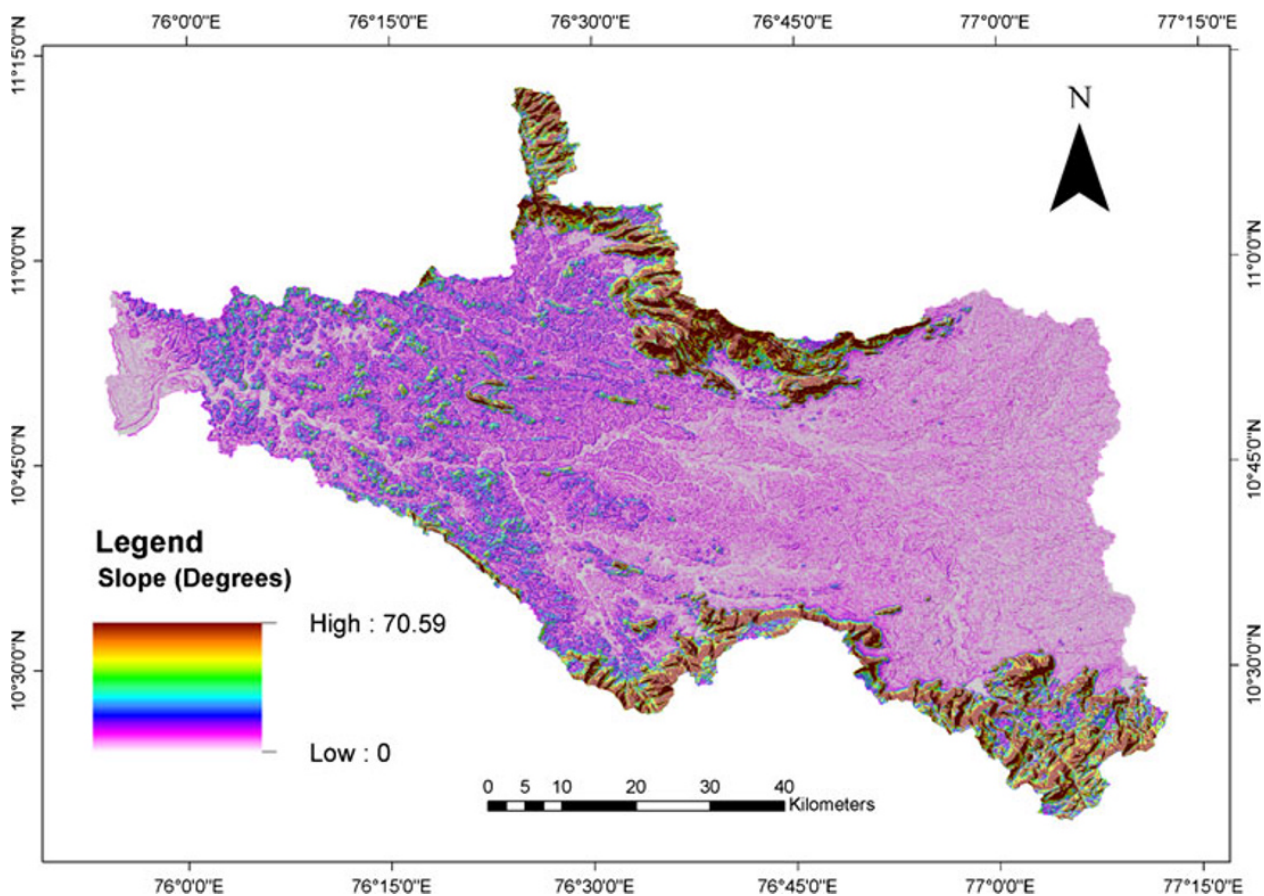

basin is shown in Fig. 5. The higher slope gradient in the study area is contributed by the hilly Western Ghats. Higher slope gradient will result in rapid runoff with potential soil loss.

\section{Stream order (u)}

The concept of stream order was introduced by Horton in 1932. Stream ordering is a widely applied method for stream classification in a river basin. Stream ordering is defined as a measure of the position of a stream in the hierarchy of tributaries (Leopold et al. 1964) and the streams of Bharathapuzha river basin have been demarcated according to the Strahler's system of stream ordering. The stream order and the total number of stream segments in each order for the basin are shown in the Table 2. Based on the Strahler (1964) system of stream ordering, the basin has been designated as a seventh-order basin (Fig. 1). In 
the present investigation, maximum frequency is observed in the first-order streams (Table 2). The first-order streams are those that do not have any tributary and these channels normally flow during the wet weather (Chow et al. 1988). More number of first-order streams is observed in the hilly region of the study area, which points towards terrain complexity and compact nature of the bedrock lithology. Moreover, the presence of large number of streams in the basin indicates that the topography is still undergoing erosion and at the same time, less number of streams indicates mature topography. The calculated result matched with Strahler (1964), which described that the total number of streams gradually decreases as the stream order increases.

\section{Stream number $(\mathrm{Nu})$}

With the help of GIS, the number of streams of different orders and the total number of streams in the basin are counted independently (Table 2). Generally, the number of streams gradually decreases as the stream order increases; the variation in order and size of tributary basins is largely depends on physiographic and structural condition of the region. 4,426 stream segments were recognized in Bharathapuzha drainage basin, out of which $78.13 \%(3,458)$ is 1st order, $16.81 \%$ (744) is 2 nd order, $3.84 \%$ (170) is $3 \mathrm{rd}$ order, $0.86 \%$ (38) is 4 th order, $0.25 \%$ (11) is 5th order, $0.09 \%$ (4) is 6th order and $0.02 \%$ comprises 7 th order stream (1) (Table 2). High values of first-order streams indicate that there is a possibility of sudden flash floods after heavy rainfall in the down streams (Chitra et al. 2011).

\section{Stream length $(\mathrm{Lu})$}

Stream length is indicative of chronological developments of the stream segments including interlude tectonic disturbances. The stream length is measured from mouth of the river to the drainage divide near the source. ' $\mathrm{Lu}$ ' has been computed on the basis of Horton's law of stream length (Table 1), which states that geometrical similarity is maintained in the basins of increasing orders. The stream length of various orders is presented in the Table 2. Generally, the total length of stream segments is the maximum in first-order streams and decreases with an increase in the stream order. The law holds true in the present case study. The results reveal that the first-order streams are short in length and are found in the upstream area; similar observations are conformed by Chitra et al. (2011). Streams with relatively short lengths are representative of areas with steep slopes and finer texture, whereas longer lengths of stream are generally indicative of low gradients (Strahler 1964).
Mean stream length (Lsm)

Mean stream length (Lsm) reveals the characteristic size of components of a drainage network and its contributing surfaces (Strahler 1964). It has been computed by dividing the total stream length of order ' $u$ ' by the number of stream segments in the order (Table 1). The Lsm values for the Bharathapuzha basin vary from 0.96 to $95.01 \mathrm{~km}$ (Table 2) with a mean Lsm value of $25.15 \mathrm{~km}$. It is noted that Lsm of any given order is greater than that of the lower order and less than that of its next higher order in the basin. The Lsm values differ with respect to different basins, as it is directly proportional to the size and topography of the basin. Strahler (1964) indicated that the Lsm is a characteristic property related to the size of drainage network and its associated surfaces.

Stream length ratio $(\mathrm{Rl})$

It is the ratio between the lengths of streams in a given order to the total length of streams in the next order (Horton 1932). The Rl values for the Bharathapuzha basin vary widely from 1.5 to 3.62 (Table 2) and are strongly dependant on the topography and the slope. Similar observations are noted in Aiyar basin (John Wilson et al. 2012) and it shows an important relationship with the surface flow discharge and the erosional stage of the basin.

\section{Bifurcation ratio $(\mathrm{Rb})$}

The term 'bifurcation ratio ( $\mathrm{Rb})$ ' was introduced by Horton in $1932 . \mathrm{Rb}$ is related to the branching pattern of a drainage network and is defined as the ratio of the number of streams of any given order to the number of streams in the next higher order in a drainage basin (Schumm 1956). It is a dimensionless property and shows the degree of integration prevailing between streams of various orders in a drainage basin. $\mathrm{Rb}$ shows a small range of variation for different regions or for different environments except those where the powerful geological control dominates. The $\mathrm{Rb}$ for the Bharathapuzha basin varies from 2.75 to 4.65 (Table 2) with a mean $\mathrm{Rb}$ of 2.62. The mean bifurcation ratio (Rbm) characteristically ranges between 3.0 and 5.0 for a basin when the influence of geological structures on the drainage network is negligible (Verstappen 1983). The analysis showed that the $\mathrm{Rb}$ is not same for all orders. Geological and lithological development of the drainage basin may be the reason for these variations (Strahler 1964). Low $\mathrm{Rb}$ value indicates poor structural disturbance and the drainage patterns have not been distorted (Strahler 1964), whereas the high $\mathrm{Rb}$ value indicates high structural complexity and low permeability of the terrain. Ket-Ord et al. (2013) also note similar $\mathrm{Rb}$ values in Upper Ing Watershed. A low

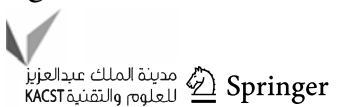


mean $\mathrm{Rb}$ value (2.62) indicates less structural disturbances in Bharathapuzha basin.

Basin length (Lb)

The basin length ( $\mathrm{Lb}$ ) is the longest length of the basin from the headwaters to the point of confluence (Gregory and Walling 1973). Bharathapuzha river originates from the Western Ghats at an altitude of about $1,100 \mathrm{~m}$ above mean sea level and drains into the Arabian Sea. The basin length determines the shape of the basin. High basin length indicates elongated basin. The Lb of the basin is $153.8 \mathrm{~km}$ (Table 2).

\section{Relief (R)}

The relief $(\mathrm{R})$ is defined as the differences in elevation between the highest and the lowest points on the valley floor of a basin. Basin relief is an important factor in understanding the denudational characteristics of the basin and plays a significant role in landforms development, drainage development, surface and sub-surface water flow, permeability and erosional properties of the terrain (Magesh et al. 2011). From the morphometric study, it should be noted that the maximum relief value of Bharathapuzha basin is $2,504 \mathrm{~m}$ (Fig. 6) and the high relief value of basin indicates the gravity of water flow, low infiltration and high runoff conditions. Magesh and Chandrasekar (2012) noted similar observations in Tamiraparani sub-basin because the presence of Western Ghats acts as a common relief-contributing factor.

\section{Relief ratio}

The relief ratio has been widely accepted as a effective measure of gradient aspect of the basin, despite uncertainties surrounding definition of its component measurements (Table 1) and may be unduly influence by one isolated peak within the basin (Sharma 1981). Schumm (1956) defined relief ratio as the ratio of maximum relief to horizontal distance along the longest dimension of a basin parallel to the main drainage line and it measures the overall steepness of the river basin. The value of relief ratio in the Bharathapuzha basin area is 0.0163 . However, in Tamiraparani sub-basin (Magesh and Chandrasekar 2012), there is a slight increase in relief ratio $(0.0261)$, but this increase is negligible as both the basin indicates the intensity of erosion processes operating on the slopes of the basin.

\section{Drainage density (Dd)}

Drainage density (Dd) is one of the important indicators of the landform element and provides a numerical measurement of landscape dissection and runoff potential (Chorley 1969). Dd is defined as the total stream length in a given basin to the total area of the basin (Strahler 1964). Dd is related to various features of landscape dissection such as valley density, channel head source area, relief (Montgomery and Dietrich 1989), climate and vegetation (Moglen et al. 1998), soil and rock properties (Smith 1958; Kelson and Wells 1989) and landscape evolution processes. A low drainage density indicates permeable sub-surface strata and has a characteristic feature of coarse drainage, which
Fig. 6 DEM map of Bharathapuzha river basin

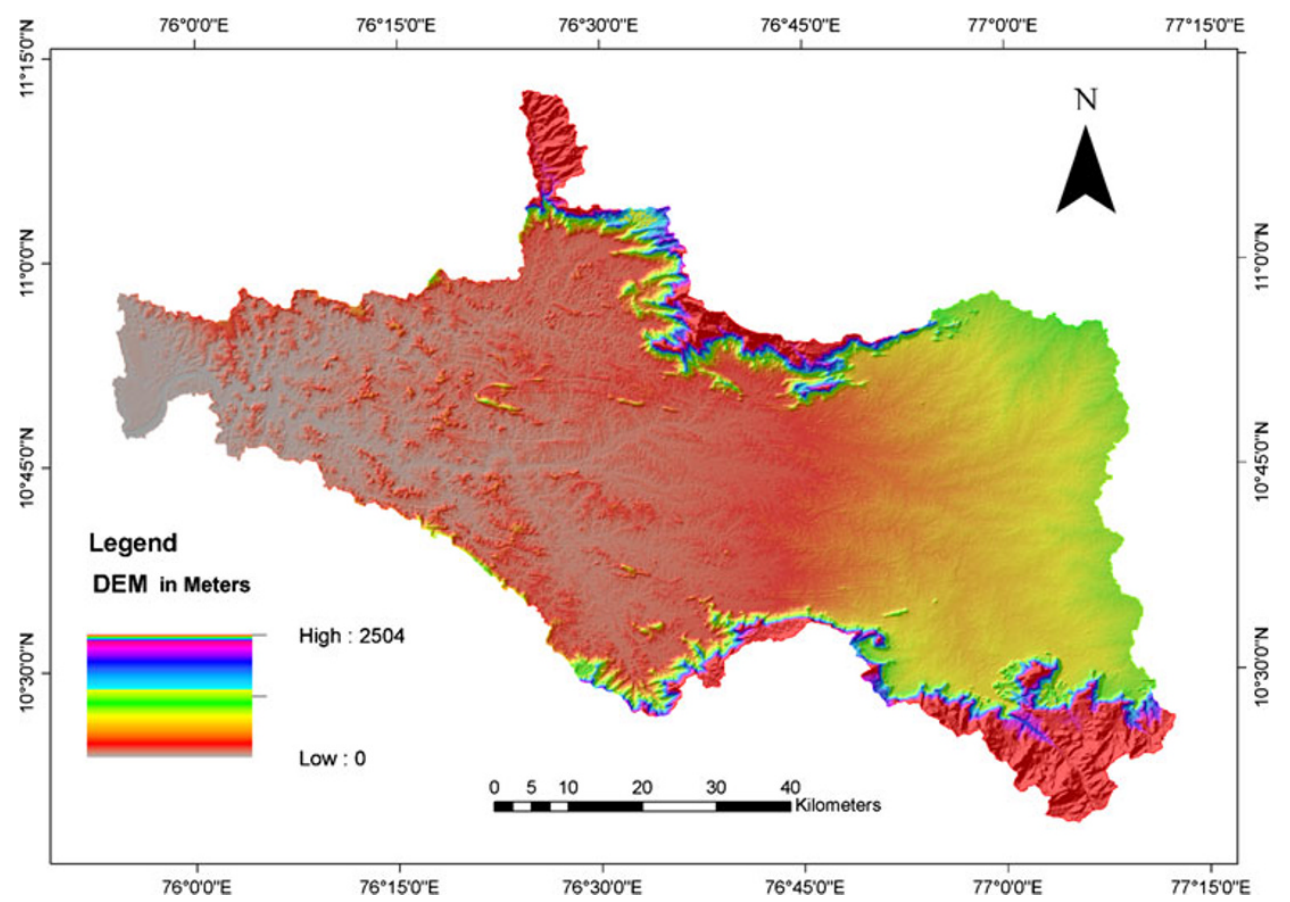


generally shows values less than 5.0. Strahler (1964) noted that low drainage density is favoured where basin relief is low and vice versa. The Dd of the Bharathapuzha basin is $1.07 \mathrm{~km} / \mathrm{km}^{2}$, which indicates that the study area has a weak or permeable subsurface material with intermediate drainage and low relief. The drainage density map for the study area is shown in Fig. 5. While comparing the study area with Tamiraparani sub-basin, a relatively high Dd is observed in the later. However, the Dd values of both the basin are less than 5.0, which indicate that both the basins have similar drainage density features.

\section{Stream frequency $(\mathrm{Fs})$}

According to Horton (1945), stream frequency (Fs) is defined as the ratio of the total number of stream segments of all the orders in the basin to the total area of the basin. 'Fs' is an index of the various stages of landscape evolution. The occurrence of stream segments depends on the nature and structure of rocks, vegetation cover, nature and amount of rainfall and soil permeability. The stream frequency for the Bharathapuzha basin is 0.74 (Table 2). The stream frequency is dependant more or less on the rainfall and the physiography of the region. Similar observations are noted in Huai Bong sub-watershed (Ket-ord et al. 2013) which has highly permeable surface and dense vegetation (Fig. 7).

Drainage texture $(\mathrm{T})$

According to Smith (1950), drainage texture (T) is a product of stream frequency and drainage density
(Table 1). The ' $T$ ' depends on underlying lithology, infiltration capacity and relief aspect of the terrain. According to Smith's classification of drainage texture, the texture value below 4 is designated as coarse; $4-10$ as intermediate; above 10 as fine and above 15 as ultra-fine texture (Table 3). The drainage texture of the Bharathapuzha basin is 7.78 , which indicates intermediate drainage texture and this ratio can be attributed to the presence of high relief in the western part of the study area (Table 2). In case of other tropical basins (Aiyar and Tamiraparani), the texture value exceeds 10 and 15 because these basins have fine to ultra-fine texture possibly formed by the cumulative effect of various geomorphological processes.

\section{Form factor $(\mathrm{Ff})$}

Horton (1932) defined form factor (Ff) as the ratio of the basin area and square root of the basin length. Long-narrow basins have larger lengths and hence smaller form factors. Circular basins have intermediate form factors, which are close to one. For a perfectly circular basin, the value of the form factor will be greater than 0.78 . Short-wide basins have the largest form factors. Bharathapuzha basin is an elongated basin with lower peak flows of longer duration due to lower Ff value (0.25) (Table 2). However, if we compare the Ff of the study area with Tamiraparani subbasin, the later have an Ff value of 0.45 that means Tamiraparani sub-basin is less elongated than the present study area.
Fig. 7 Drainage density map of Bharathapuzha river basin

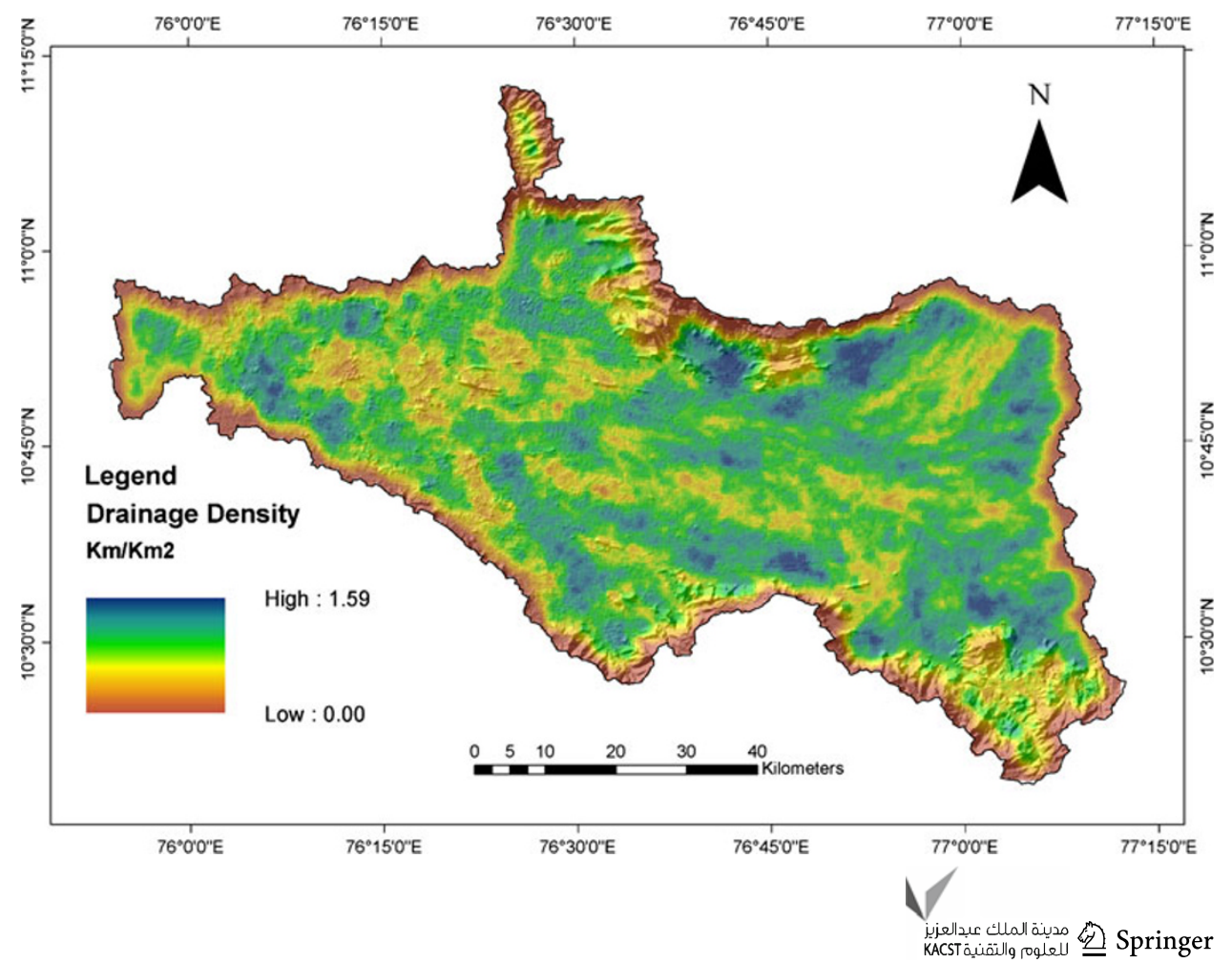


Table 3 Drainage texture (T) classification based on Smith (1950)

\begin{tabular}{ll}
\hline Range & Texture \\
\hline For 4.0 and below & Course \\
From 4.0 to 10.0 & Intermediate \\
Above 10.0 & Fine \\
Above 15.0 & Ultra fine (bad land topography)
\end{tabular}

Circulatory ratio $(\mathrm{Rc})$

Miller (1953) defined circularity ratio (Rc) as the ratio of the area of a basin to the area of a circle having the same circumference as the perimeter of the basin (Table 1). The ' $\mathrm{Rc}$ ' is influenced more by the lithological characteristics of the basin rather than anything else. The low, medium and high values of the circulatory ratio are indications of the youth mature and old stages of the life cycle of the tributary basins. Bharathapuzha basin is in the youth stage of its development with a circulatory ratio of 0.23 (Table 2). The result showed that the study area has Rc value $<0.5$, indicating elongated shape. In addition, Miller (1953) described Rc as a significant ratio that indicates the dendritic stage of a watershed. This is mainly due to the diversity of slope and relief pattern of the basin. However, in the case of Tamiraparani sub-basin, the $\mathrm{Rc}$ value is equal to 0.5 indicating more or less circular shape (Magesh and Chandrasekar 2012).

\section{Elongation ratio $(\mathrm{Re})$}

Elongation ratio $(\mathrm{Re})$ is defined as the ratio of diameter of a circle having the same area as of the basin and maximum basin length (Schumm 1956). It is a measure of the shape of the river basin and it depends on the climatic and geologic types. Generally, the Re values vary from 0.6 to 1.0 for most of the basins. The value ranges from 0.6 to 0.8 for regions of high relief and the values close to 1.0 have very low relief with circular shape. These basins are efficient in the discharge of runoff than the elongated basin because concentration time is less in circular basins. The Re value of Bharathapuzha basin is 0.57 , which indicates moderate relief with steep slope and elongated in shape. However, the Re value of Tamiraparani sub-basin (Magesh and Chandrasekar 2012) is 0.75 , which indicates that the sub-basin is less elongated with high relief and steep slope. This anomaly is due to climatic variation and basin topography.

Length of overflow (Lg)

Length of the overland flow $(\mathrm{Lg})$ is the length of water over the ground before it gets concentrated into definite stream channels. 'Lg' can be defined as the mean horizontal length of flow path from the divide to the stream in a first-order basin and is a measure of stream spacing and degree of dissection and is approximately one-half the reciprocal of the drainage density (Chorley 1969). From the morphometric analysis, the $\mathrm{Lg}$ value for Bharathapuzha basin is 1.88. The high $\mathrm{Lg}$ value indicates that the rainwater had to travel relatively longer distance before getting concentrated into stream channels (Chitra et al. 2011). However, low Lg values indicate that the rainwater will enter the stream quickly. This is true in the case of upper Ing watershed (Ket-ord et al. 2013).

\section{Conclusion}

The present study has proved that the geoprocessing technique used in GIS is an effective tool for computation and analysis of various morphometric parameters of the basin and helps to understand various terrain parameters such as nature of the bedrock, infiltration capacity, surface runoff, etc. The Bharathapuzha river is well drained in nature with the stream order varying from 1 to 7 . The basin is dominated by lower order streams and the total length of stream segments is maximum in first order streams. Bharathapuzha basin is an elongated basin with moderate relief and steep slope due to the lower elongation ratio $(0.57)$. Stream frequency and drainage density are the prime criterion for the morphometric classification of drainage basins, which certainly control the runoff pattern, sediment yield, and other hydrological parameters of the drainage basin. The Dd appears significantly lower in Bharathapuzha basin, which is an indicative of existence of impermeable rocks and moderate relief. The quantitative analysis of linear, relief and aerial parameters using GIS is found to be of immense utility in river basin evaluation, basin prioritization for soil and water conservation and natural resource management. The geoprocessing techniques employed in this study will assist the planner and decision makers in basin development and management studies.

Acknowledgments The authors sincerely thank Prof. Abdulrahman I. Alabdulaaly, editor-in-chief, Applied Water Science, for his valuable suggestions in improving the revised manuscript. We thank the two anonymous reviewers for their valuable and constructive suggestions in bringing the manuscript to its present form.

Open Access This article is distributed under the terms of the Creative Commons Attribution License which permits any use, distribution, and reproduction in any medium, provided the original author(s) and the source are credited.

\section{References}

Burrough PA (1986) Principles of geographical information systems for land resources assessment. Oxford University Press, New York, p 50 
Central Ground Water Board (CGWB) (2007) Groundwater information booklet of Thrissur District, Kerala State, pp 1-26

Chitra C, Alaguraja P, Ganeshkumari K, Yuvaraj D, Manivel M (2011) Watershed characteristics of Kundah subbasin using remote sensing and GIS techniques. Int $\mathbf{J}$ Geomatics Geosci 2(1):311-335

Chorley RJ (1969) Introduction to physical hydrology. Methuen and Co. Ltd., Suffolk, p 211

Chow Ven T, David RM, Larry WM (1988) Handbook of applied hydrology. McGraw Hill Inc., New York

Clarke JI (1996) Morphometry from maps: essay in geomorphology. Elsevier Publ., Co., New York, pp 235-274

Gregory KJ, Walling DE (1973) Drainage basin form and process: a geo-morphological approach. Edward Arnold, London

Hadley RF, Schumm SA (1961) Sediment sources and drainage basin characteristics in upper Cheyenne River Basin. USGS WaterSupply Paper 1531-B, pp 198

Horton RE (1932) Drainage basin characteristics. Trans Am Geophys Union 13:350-361

Horton RE (1945) Erosional development of streams and their drainage basins; Hydro-physical approach to quantitative morphology. Bull Geol Soc Am 56:275-370

John Wilson JS, Chandrasekar N, Magesh NS (2012) Morphometric analysis of major sub-watersheds in Aiyar and Karai Pottanar Basin, Central Tamil Nadu, India using remote sensing and GIS techniques. Bonfring Int J Indus Eng Manag Sci 2(1):8-15

Kelson KI, Wells SG (1989) Geologic influences on fluvial hydrology and bedload transport in small mountainous watersheds, northern New Mexico, USA. Earth Surf Processes 14:671-690

Ket-ord R, Tangtham N, Udomchoke V (2013) Synthesizing drainage morphology of tectonic watershed in upper ing watershed (Kwan Phayao Wetland Watershed). Modern Appl Sci 7(1):13-37

Leopold LB, Wolman MG, Miller JP (1964) Fluvial processes in geomorphology. WH Freeman and Company, San Francisco and London

Magesh NS, Chandrasekar N (2012) GIS model-based morphometric evaluation of Tamiraparani subbasin, Tirunelveli district, Tamil Nadu. India Arab J Geosci. doi:10.1007/s12517-012-0742-Z

Magesh NS, Chandrasekar N, Soundranayagam JP (2011) Morphometric evaluation of Papanasam and Manimuthar watersheds, parts of Western Ghats, Tirunelveli district, Tamil Nadu, India: a GIS approach. Environ Earth Sci 64(2):373-381

Magesh NS, Chandrasekar N, Kaliraj S (2012a) A GIS based automated extraction tool for the analysis of basin morphometry. Bonfring Int J Indus Eng Manag Sci 2(1):32-35

Magesh NS, Jitheshlal KV, Chandrasekar N, Jini KV (2012b) GIS based morphometric evaluation of Chimmini and Mupily watersheds, parts of Western Ghats, Thrissur District, Kerala, India. Earth Sci Inform 5(2):111-121
Mesa LM (2006) Morphometric analysis of a subtropical Andean basin (Tucuman, Argentina). Environ Geol 50(8):1235-1242

Miller VC (1953) A quantitative geomorphologic study of drainage basin characteristics in the clinch mountain area, Virginia and Tennessee. Columbia University, Department of Geology, Technical Report, No. 3, Contract N6 ONR 271-300

Moglen GE, Eltahir EA, Bras RL (1998) On the sensitivity of drainage density to climate change. Water Resour Res 34:855-862

Montgomery DR, Dietrich WE (1989) Source areas, drainage density and channel initiation. Water Resour Res 25:1907-1918

Nag SK, Chakraborty S (2003) Influence of rock types and structures in the development of drainage network in hard rock area. J Indian Soc Remote Sens 31(1):25-35

National Institute of Hydrology (1993) Geomorphological characteristics of Narmada basin up to Manot. CS (AR) - 128, NIH, Roorkee. Technical report, 1-34

Nautiyal MD (1994) Morphometric analysis of a drainage basin, district Dehradun, Uttar Pradesh. J Indian Soc Remote Sens 22(4):251-261

Ozdemir H, Bird D (2009) Evaluation of morphometric parameters of drainage networks derived from topographic maps and DEM in point floods. Environ Geol 56:1405-1415

Rastogi RA, Sharma TC (1976) Quantitative analysis of drainage basin characteristics. J Soil Water Conservat India 26(1-4): $18-25$

Rudraiah M, Govindaiah S, Srinivas VS (2008) Morphometry using remote sensing and GIS techniques in the sub-basins of Kagna river basin, Gulburga district, Karnataka, India. J Indian Soc Remote Sens 36:351-360

Schumm SA (1956) Evolution of drainage systems and slopes in bad lands at Perth Amboy, New Jersey. Bull Geol Soc Am 67: 597-646

Schumm SA (1963) Sinuosity of alluvial rivers in the Great Plains. Bull Geol Soc Am 74:1089-1100

Sharma HS (1981) Perspectives in geomorphology. Naurang Rai, Cocept publishing company. New Delhi-110015, pp 109-140

Smith KG (1950) Standards for grading texture of erosional topography. Am J Sci 248:655-668

Smith KG (1958) Erosional processes and landforms in badlands national monument, South Dakota. Geol Soc Am Bull 69: 975-1008

Strahler AN (1957) Quantitative analysis of watershed geomorphology. Trans Am Geophys Union 38:913-920

Strahler AN (1964) Quantitative geomorphology of drainage basins and channel networks. In: Chow ByVenTe (ed) Handbook of applied hydrology. McGraw Hill Book Company, New York

Verstappen H (1983) The applied geomorphology. International Institute for Aerial Survey and Earth Science (ITC), Enschede 